\title{
Recent advances in understanding Candida albicans hyphal
}

\section{growth [version 1; peer review: 4 approved]}

\author{
Robert A. Arkowitz, Martine Bassilana
}

Université Côte d'Azur, CNRS, Inserm, Institute of Biology Valrose, Parc Valrose, Nice, France

V1 First published: 21 May 2019, 8(F1000 Faculty Rev):700

https://doi.org/10.12688/f1000research.18546.1

Latest published: 21 May 2019, 8(F1000 Faculty Rev):700

https://doi.org/10.12688/f1000research.18546.1

\section{Abstract}

Morphological changes are critical for the virulence of a range of plant and human fungal pathogens. Candida albicans is a major human fungal pathogen whose ability to switch between different morphological states is associated with its adaptability and pathogenicity. In particular, C. albicans can switch from an oval yeast form to a filamentous hyphal form, which is characteristic of filamentous fungi. What mechanisms underlie hyphal growth and how are they affected by environmental stimuli from the host or resident microbiota? These questions are the focus of intensive research, as understanding $C$. albicans hyphal growth has broad implications for cell biological and medical research.

\section{Keywords}

morphogenesis, signaling pathways, membrane traffic, secretion, Spitzenkörper, host-interactions, cellular organization
Open Peer Review

Approval Status

1

$2 \quad 3 \quad 4$

version 1

21 May 2019

Faculty Reviews are review articles written by the prestigious Members of Faculty Opinions. The articles are commissioned and peer reviewed before publication to ensure that the final, published version is comprehensive and accessible. The reviewers who approved the final version are listed with their names and affiliations.

\section{Aaron P Mitchell, Carnegie Mellon University, Pittsburgh, USA \\ 2. Yue Wang, Institute of Molecular and Cell Biology, Agency for Science, Technology and Research, Singapore \\ 3. Malcolm Whiteway, Concordia University, Montreal, Canada \\ 4. James B Konopka, Stony Brook University, Stony Brook, USA}

Any comments on the article can be found at the end of the article. 
Corresponding authors: Robert A. Arkowitz (arkowitz@unice.fr), Martine Bassilana (Martine.BASSILANA@univ-cotedazur.fr)

Author roles: Arkowitz RA: Writing - Review \& Editing; Bassilana M: Writing - Review \& Editing

Competing interests: No competing interests were disclosed.

Grant information: This work was supported by the Centre National de la Recherche Scientifique, the Agence Nationale de la Recherche (ANR-16-CE13-0010-01 and ANR-11-LABX-0028-01), and the European Union H2020 (MSCA-ITN-2015-ETN-GA-675407) grants.

The funders had no role in study design, data collection and analysis, decision to publish, or preparation of the manuscript.

Copyright: @ 2019 Arkowitz RA and Bassilana M. This is an open access article distributed under the terms of the Creative Commons Attribution License, which permits unrestricted use, distribution, and reproduction in any medium, provided the original work is properly cited.

How to cite this article: Arkowitz RA and Bassilana M. Recent advances in understanding Candida albicans hyphal growth [version 1; peer review: 4 approved] F1000Research 2019, 8(F1000 Faculty Rev):700 https://doi.org/10.12688/f1000research.18546.1

First published: 21 May 2019, 8(F1000 Faculty Rev):700 https://doi.org/10.12688/f1000research.18546.1 


\section{Introduction}

Morphology changes occur in a range of human fungal pathogens upon interaction with the host ${ }^{1}$. In response to different host signals, Candida albicans switches from the yeast form to a hyphal form, a cell shape characteristic of filamentous fungi, such as Aspergillus nidulans and Neurospora crassa ${ }^{2-4}$. However, hyphal cells of $C$. albicans are different from those of these organisms with respect to shape/diameter and extension rate (10- to 100-fold slower with this fungal pathogen). Furthermore, in these filamentous fungi, microtubules are critical for hyphal growth, a striking difference with $C$. albicans, in which microtubules do not play a prominent role ${ }^{5}$. C. albicans is an opportunistic human fungal pathogen and a number of studies have linked the switch from yeast to hyphal form with pathogenicity, whether during superficial or systemic infections ${ }^{6-10}$. This brief review presents an update of research from the past 2 to 3 years on $C$. albicans technological advances, cell signaling, host interactions, and membrane traffic and puts an emphasis on hyphal growth (Figure 1).

\section{Technological advances}

In the past several years, technological advances have opened a range of new possibilities in $C$. albicans research. Specifically, the majority of approaches have opened our horizons with respect to large-scale analyses of fungal pathogen function, including a major thrust coming from clustered regularly interspaced short palindromic repeat (CRISPR)-based tools that have particularly revolutionized genome manipulation in genetically less accessible fungi, such as the diploid C. albicans $^{11,12}$. Other notable approaches that are changing how we work with and view this fungal pathogen include experimental or microevolution approaches ${ }^{13-15}$, in particular with respect to host niche environments. In addition, large-scale approaches, such as population and genetic diversity analyses via genome sequences of large numbers of isolates ${ }^{16}$, and the establishment of genomic platforms that facilitate the study of gene function at a genomewide level ${ }^{17-20}$ pave the way for future multi-omic studies.

The application of CRISPR-based methods to $C$. albicans in 2015 was a major step in facilitating molecular genetics in this less genetically tractable fungus ${ }^{21}$ and opened a myriad of possibilities for studying gene function, including marker recycling ${ }^{22,23}$, a "gene drive array" platform for genetic interaction ${ }^{12}$, rapid gene concatenation for genetic rescue of multi-gene mutants ${ }^{24}$, and gene regulation ${ }^{25,26}$. Overall, C. albicans CRISPR-based methods have been substantially optimized ${ }^{11,12,23,25-28}$ and now facilitate a range of gene functional analyses up to a genome-wide scale.

Experimental or micro-evolution approaches are particularly powerful tools when applied to opportunistic pathogens ${ }^{29}$. These approaches have been used initially to identify mutations that restore filamentation in a non-filamentous mutant within macrophages $^{30}$ and more recently to investigate drug resistance ${ }^{14}$, host niche-specific mutations ${ }^{13}$, and the emergence of mutualism between host and fungus ${ }^{15}$. These approaches, coupled with whole-genome sequencing and other genome-wide methods, are extremely useful when applied to a diploid commensal that can undergo a panoply of genome rearrangements with far-reaching consequences.

The application of novel large-scale approaches, as well as the refinement and optimization of existing methods to gene function analyses in $C$. albicans, will undoubtedly promote a deeper understanding of this fungal pathogen. Chemical inhibitors and chemogenomic profiling have been used to identify genes involved in enhanced antifungal drug sensitivity or resistance ${ }^{31}$ and novel inhibitors of morphogenesis ${ }^{32}$.

Genome sequencing and comparative genomics of 182 worldwide $C$. albicans isolates have revealed evidence of gene flow

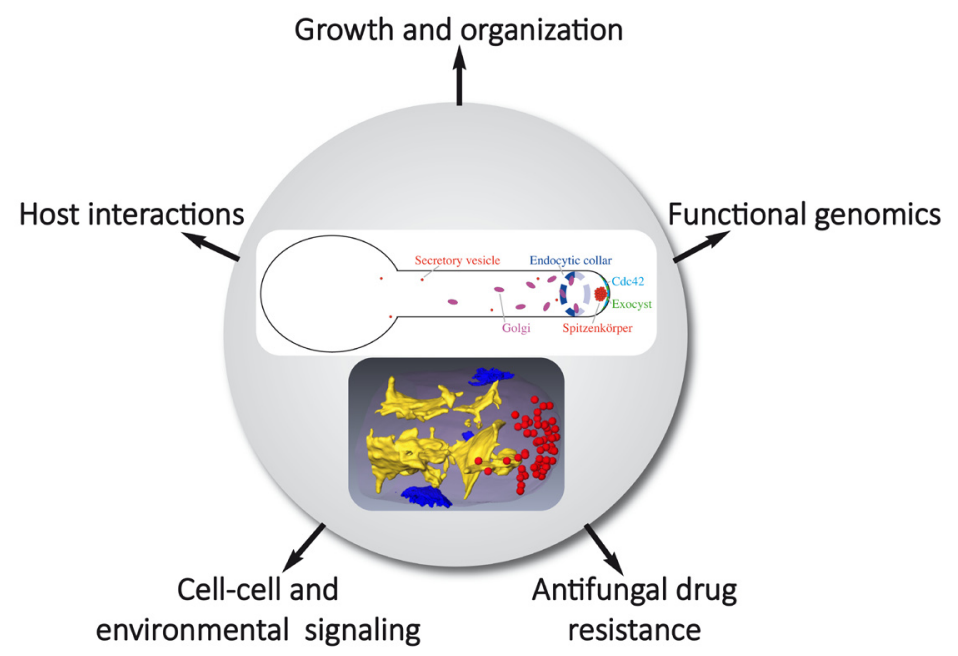

Figure 1. Schematic highlighting Candida albicans hyphal organization and studies of morphological transition in different processes and at different levels. The upper panel shows membrane compartments of the exocytic and endocytic pathways focusing on compartments discussed in the review. Endoplasmic reticulum and endosomes, for example, are not shown. The lower panel, reproduced from Weiner et al. ${ }^{33}$, illustrates a segmented three-dimensional dataset from focused ion beam/scanning electron microscopy tomography of a hyphal tip with internal membranes (yellow), secretory vesicles (red), and sites of endocytosis (blue). 
and a highly clonal lineage that has undergone substantial pseudogenization $^{16}$. In 2018, three major studies highlighted advances made possible by new gene function platforms and tools ${ }^{17-19}$. Two groups took advantage of powerful transposonbased approaches, coupled with a stable haploid $C$. albicans derivative, to probe essential genes, generate a comprehensive set of mutants in this fungus, and carry out genome-wide screens ${ }^{17,19}$. These studies yielded important information on gene essentiality and azole resistance in this fungal pathogen. Extensive effort was also invested in generating a genomic platform centered on an ORFeome collection representing the majority of open reading frames (ORFs) in Gateway donor vectors, together with a wide range of expression vectors ${ }^{18}$ facilitating genomewide overexpression analyses and protein-protein interaction studies $^{16,20,34}$. Together, these new technologies have facilitated recent advances in hyphal growth signaling, host interactions, and membrane traffic.

\section{Hyphal growth signaling}

In the past 2 to 3 years, a range of studies have investigated hyphal growth signaling in $C$. albicans $^{35}$. These studies have made significant advances, in particular in the areas of amino acid inducers of the hyphal transition ${ }^{36,37}$, gaseous sensing and signaling ${ }^{38-42}$, and reactive oxygen and oxidative stress signaling ${ }^{43-45}$. Extensive analyses of filamentation programs revealed media-independent genetic requirements for filamentation, in particular RIM101 (pH-dependent pathway) and GPA2 ( $\mathrm{G} \alpha$ functioning in the cAMP/PKA pathway), in addition to a core transcriptional profile $^{46}$. Also, an investigation into the cAMP requirement for hyphal morphogenesis showed that basal levels of cAMP are sufficient for hyphal formation in response to $\mathrm{N}$-acetylglucosamine (GlcNAc), suggesting that cAMP-independent signals are also important for hyphal induction ${ }^{47}$. Both $G_{1}$ and $S$ phase arrest can induce filamentous growth and this has been shown to require the cAMP/PKA pathway ${ }^{48}$.

Nutrient deprivation triggers hyphal development in C. albicans, and various amino acids have been shown to be critical for this transition. The groups of Van $\operatorname{Dijck}^{36}$ and Ljungdahl ${ }^{37}$ investigated cAMP/PKA-dependent morphogenesis that is triggered by arginine, ornithine, proline, and methionine metabolism. For these different amino acids, induced expression of amino acid permease genes is critical, with the former three amino acids being metabolized in the mitochondria, resulting in elevated ATP levels that appear to increase activation of the Ras1/ cAMP/PKA pathway. With respect to methionine, it is converted to $S$-adenosyl methionine (SAM) that is subsequently decarboxylated and the resulting amino-propyl group is converted to polyamines that have been shown to activate adenylate cyclase.

Although a number of studies have previously analyzed the roles of oxygen and $\mathrm{CO}_{2}$ signaling in hyphal development, there has been little attention to nitric oxide (NO) signaling in this process. Koch et al. examined a metabolic checkpoint for the yeast-to-hypha transition that is regulated by endogenous NO signaling and their results indicate that sufficient endogenous NO releases $\mathrm{Nrg} 1$ repression of this transition ${ }^{38}$. Three recent studies have shed light on how the tricarboxylic acid (TCA) cycle regulates $\mathrm{CO}_{2}$ signaling ${ }^{42}$, how a phosphatase-kinase pair controls
$\mathrm{CO}_{2}$-responsive Ume6 phosphorylation and stability ${ }^{39}$, and have identified a link between $\mathrm{CO}_{2}$ sensing and lipid/Pkh1/2 kinase signaling during hyphal development ${ }^{41}$. In the first of these studies, the authors used a library of TCA metabolic pathway mutants to show that the TCA cycle plays a critical role in regulating $\mathrm{CO}_{2}$ sensing and hyphal development ${ }^{42}$. Lu et al. carried out a genetic screen to determine the $\mathrm{CO}_{2}$ signaling pathway that regulated Ume6 stability and found that a kinase-phosphatase couple controlled the $\mathrm{CO}_{2}$ response of this transcription factor that is crucial for hyphal elongation ${ }^{39}$. A screen in Saccharomyces cerevisiae for mutants that regulate the transcription factor Cst6 (C. albicans homolog Rca1), which activates the carbonic anhydrase $\mathrm{NCE} 103$ in a $\mathrm{CO}_{2}$-dependent fashion, identified the kinase $\mathrm{Sch} 9^{41}$. The authors went on to show that Sch9 phosphorylates the transcription factor Rcal in C. albicans and that it links $\mathrm{CO}_{2}$ adaptation to lipid signaling via Pkh1/2.

The production of reactive oxygen species (ROS) during C. albicans morphogenesis plays an important role in pathogenicity. The conserved heat shock factor-like transcriptional regulator $\mathrm{Skn} 7$ is critical for filamentous growth and protection from the accumulation of intracellular ROS in these conditions $^{43}$. Interestingly, a member of the NADPH oxidase (NOX) family, Fre8, was recently shown to produce a ROS burst during morphogenesis, which is particularly important in the animal host ${ }^{45}$. Recent studies by Liu et al. have shown that inhibition of the major high-affinity phosphate importer, Pho84, sensitized $C$. albicans to oxidative stress via inducing ROS accumulation through activation of TOR (target of rapamycin) signaling ${ }^{44}$. In addition to these environmental conditions, quorum-sensing molecules, such as farnesol, regulate the morphological transition, and recent work proposed that the response of $C$. albicans to farnesol is influenced by Eed1, a protein critical for hyphal growth maintenance ${ }^{49}$. Together, these different advances in hyphal growth signaling highlight the important role of hyphal development in host niches and in response to a range of relevant host signals.

\section{Host interactions}

The microbiota is thought to, in part, restrict the fungus to the commensal state ${ }^{50}$. Of note, the GUT (gastrointestinally induced transition) cells, which are postulated to be a specialized commensal form in the mammalian gastrointestinal (GI) tract, are less virulent in a mouse bloodstream infection model ${ }^{51,52}$. The alteration of the balance between commensalism and pathogenicity in the presence of the gut microbiota is associated with mutations in $C$. albicans transcription factors required for white-opaque switching and filamentation, such as Efg1, Wor1, and Flo8 $8^{15,52,53}$. Furthermore, C. albicans strains that are hyperfit in the antibiotic-treated or germ-free mouse gut tend to be deficient in hyphal morphogenesis ${ }^{53,54}$, yet the observation that a hyperfit ume6 mutant has a ratio of yeast and hyphae similar to that of the wild-type strain in the mouse GI tract would argue that cell shape per se does not determine commensal fitness ${ }^{55}$. Using an experimental system based on long-term GI tract colonization of mice, a recent work nicely demonstrated that in the absence of microbiota $C$. albicans evolves into strains that lose their ability to form hyphae ${ }^{15}$. Interestingly, this study 
additionally shows that priming naïve mice with the gut-evolved strains resulted in a broad cross-protection against Aspergillus fumigatus, Staphylococcus aureus, or Pseudomonas aeruginosa.

Host defense also includes the epithelial physical barrier and host immune cells, such as macrophages. Hyphal growth is associated with mechanical forces during the interaction of C. albicans with such host cells $\mathrm{s}^{56}$. The relative contribution of these mechanical forces to host cell damage, compared with other hyphal attributes, is an area of active investigation. Mechanical forces appear to be sufficient to penetrate epithelial cells even in the absence of secreted factors, such as the toxin candidalysin, encoded by ECE1 and therefore secreted only by hyphae ${ }^{57}$. Indeed, ece $1 \Delta / \Delta$ mutant hyphae can invade intestinal epithelial cells without causing damage, yet optimal damage induction requires a combination of hypha formation and candidalysin secretion $^{58}$. The ability to undergo yeast-to-hypha morphogenesis and the cell wall composition are also important determinants in the macrophage- $C$. albicans interaction ${ }^{59}$. Recently, C. albicans escape from the phagolysosome was proposed to rely directly on physical rupture ${ }^{60} . C$. albicans cells induce macrophage cell death via pyroptosis, a caspase-1-dependent programmed cell death $^{61,62}$, and it was proposed that activation of the inflammasome is a consequence of this phagolysosome rupture via the yeast-to-hypha transition $^{60}$. However, this proposal was challenged by another study, which showed that rupture is not a prerequisite for inflammasome activation, as a collection of genes enabled activation of macrophage pyroptosis independently of effects on morphogenesis, and cell wall remodeling was a major determinant ${ }^{63}$. The role of candidalysin in the phagocyte inflammatory and damage response to $C$. albicans hyphae was recently investigated and this toxin appears to trigger inflammasome activation ${ }^{64}$. Thus, how $C$. albicans morphological transition, phagosomal neutralization and rupture, and pyroptosis are linked remains a topic of active research ${ }^{65,66}$.

\section{Membrane traffic and structural organization}

Secretion plays an essential role during $C$. albicans virulence, in releasing candidalysin and a variety of proteases and lipases. In addition to using the conventional secretory pathway to secrete components into the external medium, similar to other fungi, C. albicans releases extracellular vesicles $(\mathrm{EVs})^{67}$, which contain cytoplasmic and moonlighting proteins, and membrane and cell wall-related proteins ${ }^{68}$. A recent study elegantly showed that the EV population and composition released by $C$. albicans during growth in a biofilm are distinct from those of planktonic cells $^{69}$. In particular, as exogenous delivery of wild-type vesicles restores the biofilm drug-resistant phenotype and matrix composition to a subset of ESCRT (endosomal sorting complexes required for transport) mutants, it was proposed that biofilm EVs, which consist predominantly of a 30- to 200-nm diameter population, corresponding in size to exosomes, have a direct role in matrix biogenesis and carry specific cargos to confer drug resistance. The mechanism by which EVs would reach the matrix is still unclear. However, a recent work shows that AmBisome (60 to $80 \mathrm{~nm}$ liposomes) can traverse the cell wall ${ }^{70}$, suggesting that EVs may also directly transit the cell wall.

Rapid hyphal growth requires active endocytosis to counterbalance exocytosis at the hyphal tip and recycle membrane lipids and proteins ${ }^{71,72}$. For example, recent work demonstrated that polarization of a chitin synthase to the hyphal apex in A. nidulans occurs by indirect endocytic recycling ${ }^{73}$. Genetic analyses of loss-of-function mutants in a number of genes implicated in actin regulatory complexes, such as Pan $1^{74}$ and Myo5 ${ }^{75-77}$, have also confirmed the importance of endocytosis in C. albicans hyphal growth, and two recent articles further point to an increased requirement for endocytosis during hyphal growth, compared with budding growth. Taking advantage of a complete collection of kinases and phosphatases, regulated via an inducible TETon promoter, Bar-Yosef et al. ${ }^{78}$ identified a novel regulator of hyphal morphogenesis, Akl1 (related to the Ark/Prk family of kinases ${ }^{79}$ ), whose overexpression reduced hyphal extension rates and conversely whose deletion resulted in an initial increase in hyphal extension rate. Furthermore, screening of well-characterized drug libraries allowed the identification of specific inhibitors of hyphal morphogenesis, related to piperazine ${ }^{32}$. Although these drugs inhibited hyphal formation at concentrations that appear to be above safe levels, these studies raise the prospect of identifying molecules that target fungal endocytosis as potential inhibitors of $C$. albicans virulence.

Membrane/protein trafficking to the plasma membrane is mediated by vesicular transport between different cellular compartments, and small GTPases of the Arf (ADP-ribosylation factor) and Rab (Ras-related in the brain) families regulate each step of these processes ${ }^{80-82}$. The role of Arf proteins was recently investigated in hyphal growth and virulence. Of the five Arf/Arl proteins, Arf2 and Arl1 were shown to be critical for virulence in murine models for candidiasis, and Arl1 was more specifically required for oropharyngeal candidiasis ${ }^{83}$. In addition, an arfl mutant was shown to exhibit reduced virulence in a murine systemic infection model and in macrophage killing yet this strain had a reduced growth rate and underwent cell cycle $\operatorname{arrest}^{84}$. In the latter study, Arf1 was implicated as a regulator of endoplasmic reticulum (ER)-mitochondria interactions, which would directly or indirectly impact ERMES (ER-mitochondria encounter structure). Whereas Arf2 is required for viability, Arl1 is involved in hyphal extension and in restricting hyphal growth to a single site. The hyphal extension defect of the arll mutant was associated with an altered distribution of the Rab GTPase Sec4 and both defects could be restored by overexpression of the Rab GTPase Ypt6 ${ }^{83,85}$, suggesting that a genetic interaction between Arl1 and Ypt6, perhaps via the GARP (Golgi-associated retrograde protein) complex ${ }^{86}$, could be specifically critical for hyphal growth. In $S$. cerevisiae, analysis of trafficking mutants demonstrated that the late stage of exocytosis is particularly critical to regulate endocytosis ${ }^{87}$, and more recently it was shown that Sec4 coordinated polarized exocytosis with the assembly of cortical actin patches that initiate endocytosis ${ }^{88}$, indicating that this Rab GTPase is central for the balance in membrane trafficking.

Individual Rab GTPases can coordinate multiple transport pathways by recruiting effectors to different organelles ${ }^{89}$, and the importance of Rab GTPases during hyphal growth has been investigated in filamentous fungi, such as A. nidulans and $N$. crassa $a^{3,90}$. However, as mentioned above, the differences in hyphal growth in these fungi, compared with $C$. albicans, raise the 
question as to how hyphae are organized to regulate membrane traffic in this organism (Figure 1). Using three-dimensional electron microscopy, a high-resolution view of the $C$. albicans hyphal filament shows that the secretory pathway is organized in three distinct structural domains: sheet-like parallel membranes, shorter sheet-like membranes, and the Spitzenkörper (Spk), which is composed of a uniform population of approximately 60 vesicles that are about $70 \mathrm{~nm}$ in diameter ${ }^{33}$. Thus, the $C$. albicans Spk appears to be simpler than that of filamentous fungi, which is composed of a heterogeneous population of vesicles $^{2-4}$. Dynamic analyses of vesicle delivery to the apex suggest that short-range vesicle delivery significantly contributes to filamentous growth in C. albicans and that the Spk could act as a focal point for incoming secretory vesicle traffic, produced in the subapical and apex regions ${ }^{33}$. These distinctions between the Spk of $C$. albicans and that of filamentous fungi might reflect differences in their function. In particular, a characteristic shape change of the Spk, from globular to crescent-like, appeared to be associated with increased extension rate in A. nidulans, as secretory vesicles accumulated at the Spk during phases of slow growth subsequently fused with the plasma membrane ${ }^{91}$. Such a stepwise growth mode in hyphae has been shown in several filamentous fungi ${ }^{92,93}$ but thus far not in C. albicans.

\section{Conclusions}

Overall, this broad range of findings in the past several years has provided both exciting novel approaches and new research directions that give us insight into the biology of this fascinating fungal pathogen. As we understand, in greater detail, the basic biology of this fungus, we now can put this new knowledge into the context of the host and the balance between commensalism and infection. Without a doubt, the advent of new technologies, in particular the combination of large-scale approaches, and effectively mixing and matching them with animal-based studies will provide powerful platforms for novel gene discovery and functional analyses in the years ahead.

\section{Grant information}

This work was supported by the Centre National de la Recherche Scientifique, the Agence Nationale de la Recherche (ANR-16CE13-0010-01 and ANR-11-LABX-0028-01), and the European Union H2020 (MSCA-ITN-2015-ETN-GA-675407) grants.

The funders had no role in study design, data collection and analysis, decision to publish, or preparation of the manuscript.
1. Li Z, Nielsen K: Morphology Changes in Human Fungal Pathogens upon Interaction with the Host. J Fungi (Basel). 2017; 3(4): pii: 66. PubMed Abstract | Publisher Full Text | Free Full Text

2. Riquelme M, Aguirre J, Bartnicki-Garcia $\mathrm{S}$, et al.: Fungal Morphogenesis, from the Polarized Growth of Hyphae to Complex Reproduction and Infection Structures. Microbiol Mol Biol Rev. 2018; 82(2): pii: e00068-17. PubMed Abstract | Publisher Full Text | Free Full Text

3. Riquelme M, Martinez-Nunez L: Hyphal ontogeny in Neurospora crassa: a model organism for all seasons [version 1; peer review: 3 approved]. F1000Res. 2016; 5(F1000 Faculty Rev): 2801.

PubMed Abstract | Publisher Full Text | Free Full Text

4. Steinberg G, Penalva MA, Riquelme M, et al.: Cell Biology of Hyphal Growth. Microbiol Spectr. 2017; 5(2): 4364-4378. PubMed Abstract | Publisher Full Text

5. Rida PC, Nishikawa A, Won GY, et al:: Yeast-to-hyphal transition triggers formindependent Golgi localization to the growing tip in Candida albicans. Mol Biol Cell. 2006; 17(10): 4364-4378.

PubMed Abstract | Publisher Full Text | Free Full Text

6. O'Meara TR, Veri AO, Ketela T, et al.: Global analysis of fungal morphology exposes mechanisms of host cell escape. Nat Commun. 2015; 6: 6741. PubMed Abstract | Publisher Full Text | Free Full Text

7. Peters BM, Palmer GE, Nash AK, et al.: Fungal morphogenetic pathways are required for the hallmark inflammatory response during Candida albicans vaginitis. Infect Immun. 2014; 82(2): 532-543. PubMed Abstract | Publisher Full Text | Free Full Text

8. Sellam A, Whiteway M: Recent advances on Candida albicans biology and virulence [version 1; peer review: 2 approved]. F1000Res. 2016; 5(F1000 Faculty Rev): 2582.

PubMed Abstract | Publisher Full Text | Free Full Text

9. Sharma J, Rosiana S, Razzaq I, et al.: Linking Cellular Morphogenesis with Antifungal Treatment and Susceptibility in Candida Pathogens. J Fungi (Basel). 2019; 5(1): pii: E17.

PubMed Abstract | Publisher Full Text | Free Full Text

10. Vila T, Romo JA, Pierce CG, et al.: Targeting Candida albicans filamentation for antifungal drug development. Virulence. 2017; 8(2): 150-158. PubMed Abstract | Publisher Full Text | Free Full Text

11. F Halder V, Porter CBM, Chavez A, et al:: Design, execution, and analysis of CRISPR-Cas9-based deletions and genetic interaction networks in the fungal pathogen Candida albicans. Nat Protoc. 2019; 14(3): 955-975. PubMed Abstract | Publisher Full Text | F1000 Recommendation

12. F Shapiro RS, Chavez A, Porter CBM, et al.: A CRISPR-Cas9-based gene drive platform for genetic interaction analysis in Candida albicans. Nat Microbiol. 2018; 3(1): 73-82.

PubMed Abstract | Publisher Full Text | Free Full Text | F1000 Recommendation

13. $\mathrm{F}$ Ene IV, Farrer RA, Hirakawa MP, et al.: Global analysis of mutations driving microevolution of a heterozygous diploid fungal pathogen. Proc Natl Acad Sci U S A. 2018; 115(37): E8688-E8697.

PubMed Abstract | Publisher Full Text | Free Full Text | F1000 Recommendation

14. F Popp C, Ramirez-Zavala B, Schwanfelder S, et al:: Evolution of FluconazoleResistant Candida albicans Strains by Drug-Induced Mating Competence and Parasexual Recombination. mBio. 2019; 10(1): pii: e02740-18. PubMed Abstract | Publisher Full Text | Free Full Text | F1000 Recommendation

15. F Tso GHW, Reales-Calderon JA, Tan ASM, et al:: Experimental evolution of a fungal pathogen into a gut symbiont. Science. 2018; 362(6414): 589-595. PubMed Abstract | Publisher Full Text | F1000 Recommendation

16. F Ropars J, Maufrais C, Diogo D, et al:: Gene flow contributes to diversification of the major fungal pathogen Candida albicans. Nat Commun. 2018; 9(1): 2253

PubMed Abstract | Publisher Full Text | Free Full Text | F1000 Recommendation

17. $\mathrm{F}$ Gao J, Wang $\mathrm{H}, \mathrm{Li} \mathrm{Z}$, et al.: Candida albicans gains azole resistance by altering sphingolipid composition. Nat Commun. 2018; 9(1): 4495. PubMed Abstract | Publisher Full Text | Free Full Text | F1000 Recommendation

18. $\mathrm{F}$ Legrand M, Bachellier-Bassi S, Lee KK, et al.: Generating genomic platforms to study Candida albicans pathogenesis. Nucleic Acids Res. 2018; 46(14): 6935-6949. PubMed Abstract | Publisher Full Text | Free Full Text | F1000 Recommendation

19. F Segal ES, Gritsenko V, Levitan A, et al.: Gene Essentiality Analyzed by In Vivo Transposon Mutagenesis and Machine Learning in a Stable Haploid Isolate of Candida albicans. mBio. 2018; 9(5): pii: e02048-18. PubMed Abstract | Publisher Full Text | Free Full Text | F1000 Recommendation

20. F Znaidi S, van Wijlick L, Hernández-Cervantes A, et al:: Systematic gene overexpression in Candida albicans identifies a regulator of early adaptation to the mammalian gut. Cell Microbiol. 2018; 20(11): e12890. PubMed Abstract | Publisher Full Text | Free Full Text | F1000 Recommendation

21. F Vyas VK, Barrasa MI, Fink GR: A Candida albicans CRISPR system permits genetic engineering of essential genes and gene families. Sci Adv. 2015; 1(3): e1500248.

PubMed Abstract | Publisher Full Text | Free Full Text | F1000 Recommendation

22. Huang MY, Mitchell AP: Marker Recycling in Candida albicans through CRISPRCas9-Induced Marker Excision. mSphere. 2017; 2(2): pii: e00050-17. PubMed Abstract | Publisher Full Text | Free Full Text 
23. Nguyen N, Quail MMF, Hernday AD: An Efficient, Rapid, and Recyclable System for CRISPR-Mediated Genome Editing in Candida albicans. mSphere. 2017; 2(2): pii: e00149-17

PubMed Abstract | Publisher Full Text | Free Full Text

24. Huang MY, Woolford CA, Mitchell AP: Rapid Gene Concatenation for Genetic Rescue of Multigene Mutants in Candida albicans. mSphere. 2018; 3(2): pii: e00169-18.

PubMed Abstract | Publisher Full Text | Free Full Text

25. Roman E, Coman I, Prieto D, et al.: Implementation of a CRISPR-Based System for Gene Regulation in Candida albicans. mSphere. 2019; 4(1): pii: e00001-19. PubMed Abstract | Publisher Full Text | Free Full Text

26. Wensing L, Sharma J, Uthayakumar D, et al:: A CRISPR Interference Platform for Efficient Genetic Repression in Candida albicans. mSphere. 2019; 4(1): pii: e00002-19.

PubMed Abstract | Publisher Full Text | Free Full Text

27. $\mathrm{Ng} \mathrm{H}$, Dean N: Dramatic Improvement of CRISPR/Cas9 Editing in Candida albicans by Increased Single Guide RNA Expression. mSphere. 2017; 2(2) pii: e00385-16.

PubMed Abstract | Publisher Full Text | Free Full Text

28. F Vyas VK, Bushkin GG, Bernstein DA, et al:: New CRISPR Mutagenesis Strategies Reveal Variation in Repair Mechanisms among Fungi. $m S p h e r e$ 2018; 3(2): pii: e00154-18.

PubMed Abstract | Publisher Full Text | Free Full Text | F1000 Recommendation

29. Pais $\mathrm{P}, \mathrm{Galocha} \mathrm{M}$, Viana R, et al.: Microevolution of the pathogenic yeasts Candida albicans and Candida glabrata during antifungal therapy and host infection. Microb Cell. 2019; 6(3): 142-159. PubMed Abstract | Publisher Full Text | Free Full Text

30. F Wartenberg A, Linde J, Martin R, et al.: Microevolution of Candida albicans in macrophages restores filamentation in a nonfilamentous mutant. PLOS Genet. 2014; 10(12): e1004824.

PubMed Abstract | Publisher Full Text | Free Full Text | F1000 Recommendation

31. Chen Y, Mallick J, Maqnas A, et al.: Chemogenomic Profiling of the Fungal Pathogen Candida albicans. Antimicrob Agents Chemother. 2018; 62(2): pii: e02365-17.

PubMed Abstract | Publisher Full Text | Free Full Text

32. Bar-Yosef H, Vivanco Gonzalez N, Ben-Aroya S, et al:: Chemical inhibitors of Candida albicans hyphal morphogenesis target endocytosis. Sci Rep. 2017; 7(1): 5692

PubMed Abstract | Publisher Full Text | Free Full Text

33. F Weiner A, Orange F, Lacas-Gervais S, et al:: On-site secretory vesicle delivery drives filamentous growth in the fungal pathogen Candida albicans. Cell Microbiol. 2019; 21(1): e12963.

PubMed Abstract | Publisher Full Text | F1000 Recommendation

34. F Schoeters F, Munro CA, d'Enfert C, et al:: A High-Throughput Candida albicans Two-Hybrid System. $m$ Sphere. 2018; 3(4): pii: e00391-18. PubMed Abstract | Publisher Full Text | Free Full Text | F1000 Recommendation

35. Kornitzer D: Regulation of Candida albicans Hyphal Morphogenesis by Endogenous Signals. J Fungi (Basel). 2019; 5(1): pii: E21. PubMed Abstract | Publisher Full Text | Free Full Text

36. F Schrevens $\mathrm{S}$, Van Zeebroeck G, Riedelberger $\mathrm{M}$, et al.: Methionine is required for CAMP-PKA-mediated morphogenesis and virulence of Candida albicans. Mol Microbiol. 2018; 108(3): 258-275.

PubMed Abstract | Publisher Full Text | F1000 Recommendation

37. F Silao FGS, Ward M, Ryman K, et al.: Mitochondrial proline catabolism activates Ras1/cAMP/PKA-induced filamentation in Candida albicans. PLOS Genet. 2019; 15(2): e1007976.

PubMed Abstract | Publisher Full Text | Free Full Text | F1000 Recommendation

38. F Koch B, Barugahare AA, Lo TL, et al:: A Metabolic Checkpoint for the Yeastto-Hyphae Developmental Switch Regulated by Endogenous Nitric Oxide Signaling. Cell Rep. 2018; 25(8): 2244-2258.e7. PubMed Abstract | Publisher Full Text | F1000 Recommendation

39. F Lu Y, Su C, Ray S, et al:: CO Signaling through the Ptc2-Ssn3 Axis Governs Sustained Hyphal Development of Candida albicans by Reducing Ume6 Phosphorylation and Degradation. mBio. 2019; 10(1): pii: e02320-18. PubMed Abstract | Publisher Full Text | Free Full Text | F1000 Recommendation

40. Martin R, Pohlers S, Muhlschlegel FA, et al.: $\mathrm{CO}_{2}$ sensing in fungi: at the heart of metabolic signaling. Curr Genet. 2017; 63(6): 965-972. PubMed Abstract | Publisher Full Tex

41. Pohlers S, Martin R, Kruger T, et al.: Lipid Signaling via Pkh1/2 Regulates Fungal $\mathrm{CO}_{2}$ Sensing through the Kinase Sch9. mBio. 2017; 8(1): pii: e02211-16. PublMed Abstract | Publisher Full Text | Free Full Text

42. F Tao L, Zhang Y, Fan S, et al:: Integration of the tricarboxylic acid (TCA) cycle with cAMP signaling and $\mathrm{Sfl} 2$ pathways in the regulation of $\mathrm{CO}_{2}$ sensing and hyphal development in Candida albicans. PLoS Genet. 2017; 13(8): e1006949.

PubMed Abstract | Publisher Full Text | Free Full Text | F1000 Recommendation

43. Basso V, Znaidi S, Lagage V, et al:: The two-component response regulator Skn7 belongs to a network of transcription factors regulating morphogenesis in Candida albicans and independently limits morphogenesis-induced ROS accumulation. Mol Microbiol. 2017; 106(1): 157-182.

PubMed Abstract | Publisher Full Text
44. F Liu NN, Uppuluri P, Broggi A, et al.: Intersection of phosphate transport, oxidative stress and TOR signalling in Candida albicans virulence. PLOS Pathog. 2018; 14(7): e1007076.

PubMed Abstract | Publisher Full Text | Free Full Text | F1000 Recommendation

45. F Rossi DCP, Gleason JE, Sanchez H, et al:: Candida albicans FRE8 encodes a member of the NADPH oxidase family that produces a burst of ROS during fungal morphogenesis. PLOS Pathog. 2017; 13(12): e1006763.

PubMed Abstract | Publisher Full Text | Free Full Text | F1000 Recommendation

46. Azadmanesh J, Gowen AM, Creger PE, et al.: Filamentation Involves Two Overlapping, but Distinct, Programs of Filamentation in the Pathogenic Fungus Candida albicans. G3 (Bethesda). 2017; 7(11): 3797-3808. PubMed Abstract | Publisher Full Text | Free Full Text

47. F Parrino SM, Si H, Naseem S, et al.: cAMP-independent signal pathways stimulate hyphal morphogenesis in Candida albicans. Mol Microbiol. 2017; 103(5): 764-779.

PubMed Abstract | Publisher Full Text | Free Full Text | F1000 Recommendation

48. F Chen C, Zeng G, Wang Y: G1 and S phase arrest in Candida albicans induces filamentous growth via distinct mechanisms. Mol Microbiol. 2018; 110(2): 191-203

PubMed Abstract | Publisher Full Text | F1000 Recommendation

49. Polke M, Leonhardt I, Kurzai O, et al:: Farnesol signalling in Candida albicans - more than just communication. Crit Rev Microbiol. 2018; 44(2): 230-243. PubMed Abstract | Publisher Full Text

50. F Neville BA, d'Enfert C, Bougnoux ME: Candida albicans commensalism in the gastrointestinal tract. FEMS Yeast Res. 2015; 15(7): pii: fov081. PubMed Abstract | Publisher Full Text | F1000 Recommendation

51. Noble SM, Gianetti BA, Witchley JN: Candida albicans cell-type switching and functional plasticity in the mammalian host. Nat Rev Microbiol. 2017; 15(2): 96-108.

PubMed Abstract | Publisher Full Text | Free Full Text

52. F Pande K, Chen C, Noble SM: Passage through the mammalian gut triggers a phenotypic switch that promotes Candida albicans commensalism. Nat Genet. 2013; 45(9): 1088-1091.

PubMed Abstract | Publisher Full Text | Free Full Text | F1000 Recommendation

53. Hirakawa MP, Martinez DA, Sakthikumar S, et al:: Genetic and phenotypic intraspecies variation in Candida albicans. Genome Res. 2015; 25(3): 413-425. PubMed Abstract | Publisher Full Text | Free Full Text

54. Bohm L, Torsin S, Tint SH, et al:: The yeast form of the fungus Candida albicans promotes persistence in the gut of gnotobiotic mice. PLoS Pathog. 2017; 13(10): e1006699

PubMed Abstract | Publisher Full Text | Free Full Text

55. F Witchley JN, Penumetcha P, Abon NV, et al:: Candida albicans Morphogenesis Programs Control the Balance between Gut Commensalism and Invasive Infection. Cell Host Microbe. 2019; 25(3): 432-443.e6. PubMed Abstract | Publisher Full Text | F1000 Recommendation

56. Westman J, Hube B, Fairn GD: Integrity under stress: Host membrane remodelling and damage by fungal pathogens. Cell Microbiol. 2019; 21(4): e13016.

PubMed Abstract | Publisher Full Text

57. $\mathrm{F}$ Moyes $\mathrm{DL}$, Wilson $\mathrm{D}$, Richardson JP, et al.: Candidalysin is a fungal peptide toxin critical for mucosal infection. Nature. 2016; 532(7597): 64-68. PubMed Abstract | Publisher Full Text | Free Full Text | F1000 Recommendation

58. F Allert S, Forster TM, Svensson CM, et al:: Candida albicans-Induced Epithelial Damage Mediates Translocation through Intestinal Barriers. mBio. 2018; 9(3): pii: e00915-18.

PubMed Abstract | Publisher Full Text | Free Full Text | F1000 Recommendation

59. McKenzie CG, Koser U, Lewis LE, et al.: Contribution of Candida albicans cell wall components to recognition by and escape from murine macrophages. Infect Immun. 2010; 78(4): 1650-1658.

PubMed Abstract | Publisher Full Text | Free Full Text

60. F Westman J, Moran G, Mogavero S, et al:: Candida albicans Hypha Expansion Causes Phagosomal Membrane Damage and Luminal Alkalinization. mBio. 2018; 9(5): pii: e01226-18.

PubMed Abstract | Publisher Full Text | Free Full Text | F1000 Recommendation

61. F Uwamahoro N, Verma-Gaur J, Shen $\mathrm{HH}$, et al:: The pathogen Candida albicans hijacks pyroptosis for escape from macrophages. mBio. 2014; $\mathbf{5}(2)$ : e00003-14

PubMed Abstract | Publisher Full Text | Free Full Text | F1000 Recommendation

62. F Wellington M, Koselny K, Sutterwala FS, et al:: Candida albicans triggers NLRP3-mediated pyroptosis in macrophages. Eukaryot Cell. 2014; 13(2): 329-340

PubMed Abstract | Publisher Full Text | Free Full Text | F1000 Recommendation

63. F O'Meara TR, Duah K, Guo CX, et al.: High-Throughput Screening Identifies Genes Required for Candida albicans Induction of Macrophage Pyroptosis. mBio. 2018; 9(4): pii: e01581-18.

PubMed Abstract | Publisher Full Text | Free Full Text | F1000 Recommendation

64. Kasper L, Konig A, Koenig PA, et al.: The fungal peptide toxin Candidalysin activates the NLRP3 inflammasome and causes cytolysis in mononuclear phagocytes. Nat Commun. 2018; 9(1): 4260.

PubMed Abstract | Publisher Full Text | Free Full Text 
65. O'Meara TR, Cowen LE: Insights into the host-pathogen interaction: C. albicans manipulation of macrophage pyroptosis. Microb Cell. 2018; 5(12): 566-568. PubMed Abstract | Publisher Full Text | Free Full Text

66. May RC, Casadevall A: In Fungal Intracellular Pathogenesis, Form Determines Fate. mBio. 2018; 9(5): pii: e02092-18. PubMed Abstract | Publisher Full Text | Free Full Text

67. Albuquerque PC, Nakayasu ES, Rodrigues ML, et al.: Vesicular transport in Histoplasma capsulatum: an effective mechanism for trans-cell wall transfer of proteins and lipids in ascomycetes. Cell Microbiol. 2008; 10(8): 1695-1710. PubMed Abstract | Publisher Full Text | Free Full Text

68. Vargas G, Rocha JD, Oliveira DL, et al:: Compositional and immunobiological analyses of extracellular vesicles released by Candida albicans. Cell Microbiol. 2015; 17(3): 389-407.

PubMed Abstract | Publisher Full Text

69. F Zarnowski R, Sanchez H, Covelli AS, et al:: Candida albicans biofilm-induced vesicles confer drug resistance through matrix biogenesis. PLOS Biol. 2018; 16(10): e2006872.

PubMed Abstract | Publisher Full Text | Free Full Text | F1000 Recommendation

70. F Walker L, Sood P, Lenardon MD, et al: The Viscoelastic Properties of the Fungal Cell Wall Allow Traffic of AmBisome as Intact Liposome Vesicles. mBio. 2018; 9(1): pii: e02383-17.

PubMed Abstract | Publisher Full Text | Free Full Text | F1000 Recommendation

71. Bartnicki-Garcia S, Garduño-Rosales M, Delgado-Alvarez DL, et al.: Experimental measurement of endocytosis in fungal hyphae. Fungal Genet Biol. 2018; 118: 32-36.

PubMed Abstract | Publisher Full Text

72. Shaw $\mathrm{BD}$, Chung DW, Wang $\mathrm{CL}$, et al:: A role for endocytic recycling in hyphal growth. Fungal Biol. 2011; 115(6): 541-546. PubMed Abstract | Publisher Full Text

73. F Hernández-González M, Bravo-Plaza I, Pinar M, et al.: Endocytic recycling via the TGN underlies the polarized hyphal mode of life. PLOS Genet. 2018; 14(4): e1007291.

PubMed Abstract | Publisher Full Text | Free Full Text | F1000 Recommendation

74. Martin R, Hellwig D, Schaub Y, et al.: Functional analysis of Candida albicans genes whose Saccharomyces cerevisiae homologues are involved in endocytosis. Yeast. 2007; 24(6): 511-522 PubMed Abstract | Publisher Full Text

75. Oberholzer $\mathrm{U}$, Marcil $\mathrm{A}$, Leberer $\mathrm{E}$, et al:: Myosin I is required for hypha formation in Candida albicans. Eukaryot Cell. 2002; 1(2): 213-228. PubMed Abstract | Publisher Full Text | Free Full Text

76. Oberholzer U, Nantel A, Berman J, et al:: Transcript profiles of Candida albicans cortical actin patch mutants reflect their cellular defects: contribution of the Hog1p and Mkc1p signaling pathways. Eukaryot Cell. 2006; 5(8): 1252-1265. PubMed Abstract | Publisher Full Text | Free Full Text

77. Borth N, Walther A, Reijnst $\mathrm{P}$, et al.: Candida albicans Vrp1 is required for polarized morphogenesis and interacts with Wal1 and Myo5. Microbiology. 2010; 156(Pt 10): 2962-2969.

PubMed Abstract | Publisher Full Text

78. Bar-Yosef H, Gildor T, Ramirez-Zavala B, et al:: A Global Analysis of Kinase Function in Candida albicans Hyphal Morphogenesis Reveals a Role for the
Endocytosis Regulator Akl1. Front Cell Infect Microbiol. 2018; 8: 17. PubMed Abstract | Publisher Full Text | Free Full Text

79. Smythe E, Ayscough KR: The Ark1/Prk1 family of protein kinases. Regulators of endocytosis and the actin skeleton. EMBO Rep. 2003; 4(3): 246-251. PubMed Abstract | Publisher Full Text | Free Full Text

80. Donaldson JG, Jackson CL: ARF family G proteins and their regulators: roles in membrane transport, development and disease. Nat Rev Mol Cell Biol. 2011; 12(6): 362-375.

PubMed Abstract | Publisher Full Text | Free Full Text

81. Segev N: Coordination of intracellular transport steps by GTPases. Semin Cell Dev Biol. 2011; 22(1): 33-38.

PubMed Abstract | Publisher Full Text | Free Full Text

82. Mizuno-Yamasaki E, Rivera-Molina F, Novick P: GTPase networks in membrane traffic. Annu Rev Biochem. 2012; 81: 637-659.

PubMed Abstract | Publisher Full Text | Free Full Text

83. Labbaoui $\mathrm{H}$, Bogliolo S, Ghugtyal V, et al: Role of Arf GTPases in fungal morphogenesis and virulence. PLOS Pathog. 2017; 13(2): e1006205. PubMed Abstract | Publisher Full Text | Free Full Text

84. Zhang B, Yu Q, Huo D, et al:: Arf1 regulates the ER-mitochondria encounter structure (ERMES) in a reactive oxygen species-dependent manner. FEBS J. 2018; 285(11): 2004-2018.

PubMed Abstract | Publisher Full Text

85. Wakade R, Labbaoui H, Stalder D, et al:: Overexpression of YPT6 restores nvasive filamentous growth and secretory vesicle clustering in a Candida albicans arl1 mutant. Small GTPases. 2017; 1-7. PubMed Abstract | Publisher Full Text

86. $\mathrm{F}$ Tong $\mathrm{AH}$, Lesage $\mathrm{G}$, Bader GD, et al.: Global mapping of the yeast genetic interaction network. Science. 2004 303(5659): 808-813. PubMed Abstract | Publisher Full Text | F1000 Recommendation

87. Jose $\mathrm{M}$, Tollis $\mathrm{S}$, Nair $\mathrm{D}$, et al:: A quantitative imaging-based screen reveals the exocyst as a network hub connecting endocytosis and exocytosis. Mol Biol Cell. 2015; 26(13): 2519-2534. PubMed Abstract | Publisher Full Text | Free Full Text

88. Johansen J, Alfaro G, Beh CT: Polarized Exocytosis Induces Compensatory Endocytosis by Sec4p-Regulated Cortical Actin Polymerization. PLOS Biol. 2016; 14(8): e1002534.

PubMed Abstract | Publisher Full Text | Free Full Text

89. Lipatova Z, Hain AU, Nazarko VY, et al:: Ypt/Rab GTPases: principles learned from yeast. Crit Rev Biochem Mol Biol. 2015; 50(3): 203-211.

PubMed Abstract | Publisher Full Text | Free Full Text

90. Pantazopoulou A: The Golgi apparatus: insights from filamentous fungi. Mycologia. 2016; 108(3): 603-622. PubMed Abstract | Publisher Full Tex

91. Zhou L, Evangelinos M, Wernet V, et al: Superresolution and pulse-chase imaging reveal the role of vesicle transport in polar growth of fungal cells. $S c i$ Adv. 2018; 4(1): e1701798.

PubMed Abstract | Publisher Full Text | Free Full Text

92. Lopez-Franco R, Bartnicki-Garcia S, Bracker CE: Pulsed growth of fungal hyphal tips. Proc Natl Acad Sci U S A. 1994; 91(25): 12228-12232. PubMed Abstract | Publisher Full Text | Free Full Text

93. Takeshita N: Oscillatory fungal cell growth. Fungal Genet Biol. 2018; 110: 10-14. PubMed Abstract | Publisher Full Text 


\section{Open Peer Review}

\section{Current Peer Review Status:}

\section{Editorial Note on the Review Process}

Faculty Reviews are review articles written by the prestigious Members of Faculty Opinions. The articles are commissioned and peer reviewed before publication to ensure that the final, published version is comprehensive and accessible. The reviewers who approved the final version are listed with their names and affiliations.

\section{The reviewers who approved this article are:}

\section{Version 1}

\section{James B Konopka}

Department of Molecular Genetics and Microbiology, Stony Brook University, Stony Brook, NY, USA Competing Interests: No competing interests were disclosed.

2. Malcolm Whiteway Department of Biology, Concordia University, Montreal, Quebec, Canada

Competing Interests: No competing interests were disclosed.

\section{Yue Wang}

Institute of Molecular and Cell Biology, Agency for Science, Technology and Research, Singapore

Competing Interests: No competing interests were disclosed.

\section{Aaron P Mitchell}

Department of Biological Sciences, Carnegie Mellon University, Pittsburgh, PA, USA

Competing Interests: No competing interests were disclosed.

The benefits of publishing with F1000Research:

- Your article is published within days, with no editorial bias

- You can publish traditional articles, null/negative results, case reports, data notes and more

- The peer review process is transparent and collaborative

- Your article is indexed in PubMed after passing peer review

- Dedicated customer support at every stage

For pre-submission enquiries, contact research@f1000.com 